\title{
GAMBARAN TINGGI BADAN SEBELUM TIDUR DAN SETELAH BANGUN PAGI PADA MAHASISWA FAKULTAS KEDOKTERAN UNSRAT MANADO
}

\author{
${ }^{1}$ Riandy A. T. Pattuju \\ ${ }^{2}$ George N. Tanudjaja \\ ${ }^{2}$ Martha M. Kaseke
}

\author{
${ }^{1}$ Kandidat Skripsi Fakultas Kedokteran Universitas Sam Ratulangi Manado \\ ${ }^{2}$ Bagian Anatomi-Histologi Fakultas Kedokteran Universitas Sam Ratulangi Manado \\ Email: riandyanugrah@gmail.com
}

\begin{abstract}
Anthropometry is a measurement of the parts of human body. Nowadays there are so many studies and theories about anthropometry. One of them is difference between measurement of morning body height and evening body height. People should be taller in the morning than in the evening. This study's goal is to obtain the description of human body height at different measurement time, by the time after morning wake-up and before sleep in the night from the students at Medical Faculty of Sam Ratulangi University in Manado. This study is a descriptive study with the cross-sectional approach. Samples were taken by purposive sampling. The amount of sample was calculated based on Slovin formula, with the total amount of sample is 75 people. The result showed that there is a body height step-up when the body height is measured after morning wake-up than before night sleep. The average of man's body height step-up is $1.5 \mathrm{~cm}$ height and woman's body height step-up is $1,6 \mathrm{~cm}$ height. T-test showed that there is a significant difference of body height between before sleep and after morning wake up with the value of $p<0.01$. Conclusion: The research can be concluded that there is a significant difference between before night sleep and after morning wake-up body height, in which the height step-up happens in the morning than in the evening.
\end{abstract}

Keywords: body height, before sleeping, after waking up

\begin{abstract}
Abstrak: Antropometri merupakan pengukuran terhadap bagian-bagian tubuh manusia. Saat ini sudah banyak penelitian dan teori tentang antropometri. Salah satunya adalah terdapat perbedaan hasil pengukuran tinggi badan pada pagi dan malam hari. Seseorang dapat menjadi lebih tinggi pada pagi hari dibandingkan pada malam hari. Penelitian ini bertujuan untuk melihat gambaran tinggi badan yang diukur pada 2 waktu yang berbeda, yaitu setelah bangun pagi dan sebelum tidur pada mahasiswa Fakultas Kedokteran UNSRAT Manado. Penelitian ini merupakan penelitian deskriptif dengan pendekatan potong silang. Sampel diambil secara purposive sampling. Besar sampel dihitung dengan rumus Slovin dengan jumlah sampel penelitian 75 orang. Hasil penelitian menunjukkan bahwa terdapat peningkatan tinggi badan pada pengukuran setelah bangun pagi dibandingkan sebelum tidur. Rata-rata peningkatan pada laki-laki sebesar $1,5 \mathrm{~cm}$ dan perempuan 1,6 cm. Melalui uji t didapatkan bahwa terdapat perbedaan signifikan antara tinggi badan sebelum tidur dan setelah bangun pagi dengan nilai $\mathrm{p}<0,01$. Simpulan: Dapat disimpulkan bahwa terdapat perbedaan signifikan antara tinggi badan sebelum tidur dan setelah bangun pagi, dimana terjadi peningkatan tinggi badan pada pagi hari dibandingkan malam hari.
\end{abstract}

Kata kunci: tinggi badan, sebelum tidur, setelah bangun pagi 
Antropometri merupakan pengukuran terhadap tubuh manusia. Menurut National Health And Nutrition Examination Survey, antropometri merupakan studi tentang pengukuran tinggi badan, berat badan, bahkan pengukuran lainnya seperti lipatan kulit dan lingkar tubuh. ${ }^{1}$ Antopometri merupakan ilmu yang terus berkembang seiring dengan banyaknya penelitianpenelitian mengenai antropometri dan teori-teori yang ada berdasarkan hasil penelitian tersebut.

Salah satu teori dalam bidang antropometri adalah tinggi badan dapat bertambah pada pagi hari dibandingkan malam hari. Hal ini disebabkan karena adanya pengaruh dari aktivitas manusia, sehingga menyebabkan perubahan panjang kolumna vertebralis selama aktivitas. Selama istirahat, terjadi penambahan panjang kolumna vertebralis akibat pengurangan beban kolumna vertebralis selama tidur dibandingkan selama aktivitas.

Penelitian yang dilakukan oleh Roush dkk (2008) tentang Perubahan Vertebral Column Height (VCH) menunjukkan bahwa aktvitas seperti berjalan dapat mempengaruhi tinggi kolumna vertebralis. Tinggi kolumna vertebralis dapat berkurang tergantung dari seberapa jauh jarak yang ditempuh pada waktu berjalan. ${ }^{2}$

Kompresi aksial merupakan faktor yang berpengaruh terhadap Vertebral Column Height (VCH). Kompresi aksial dapat terjadi selama pemberian beban, positi tubuh, maupun aktivitas. O'Connell dkk (2007) meneliti tentang ketebalan diskus pre kompresi dan saat kompresi dengan menggunakan Magnetic Resonance Imaging (MRI). Hasil penelitian menunjukkan bahwa kompresi memengaruhi ketebalan diskus intervertebralis. Perbedaan ketebalan diksus intervertebralis pre kompresi dan saat kompresi yang tampak pada MRI yaitu 0,8-1,5 mm, dimana pengurangan ketebalan diskus terjadi selama kompresi. ${ }^{3}$

Aktivitas sehari-hari dapat memengaruhi tinggi kolumna vertebralis sehingga pengukuran tinggi badan seseorang dapat menunjukkan hasil yang berbeda berdasar- kan waktu pengukuran (malam dan pagi hari). Penelitian ini bertujuan untuk melihat gambaran tinggi badan sebelum tidur dan setelah bangun pagi pada mahasiswa Fakultas Kedokteran Unsrat Manado.

\section{METODE PENELITIAN}

Desain penelitian yang digunakan adalah penelitian deskriptif dengan pendekatan cross-sectional. Subjek penelitian ialah mahasiswa dan mahasiswa semester VII Fakultas Kedokteran UNSRAT yang telah memenuhi kriteria inklusi dan eksklusi. Penelitian berlangsung pada bulan Oktober - Desember 2014, dengan besar subjek penelitian yaitu 75 orang. Pengukuran tinggi badan dilakukan menggunakan alat bantu staturemeter (microtoise) dan mengikuti standar baku prosedur pengukuran tinggi badan. Tinggi badan subjek diukur pada 2 waktu yang berbeda, yaitu sebelum tidur malam dan setelah bangun pagi dengan waktu tidur cukup ( \pm 8 jam).

\section{HASIL PENELITIAN}

Berdasarkan hasil pengukuran tinggi badan sebelum tidur dan setelah bangun pagi pada mahasiswa semester VII Fakultas Kedokteran UNSRAT pada bulan OktoberDesember 2014, didapatkan hasil sebagai berikut :

\section{Distribusi subjek penelitian berdasarkan umur}

Berdasarkan distrubusi umur, subjek penelitian ini berumur 19-23 tahun Sebagian besar subjek berumur 21 tahun yaitu sebanyak 50 orang $(66,67 \%)$ diikuti oleh usia 19 tahun berjumlah 1 orang (1,3\%), 20 tahun berjumlah 12 orang (16\%), 22 tahun berjumlah 11 orang (14,\%), dan 23 tahun berjumlah 1 orang (1,3\%) (Tabel 1).

\section{Distribusi subjek penelitian berdasarkan jenis kelamin}

Berdasarkan jenis kelamin, subjek penelitian laki-laki berjumlah 39 orang dan perempuan 36 orang (Tabel 2). 
Tabel 1. Distribusi subjek penelitian berdasarkan umur

\begin{tabular}{ccc}
\hline Umur & $\begin{array}{c}\text { Jumlah } \\
\text { subjek }\end{array}$ & $\begin{array}{c}\text { Persentasi } \\
\mathbf{( \% )}\end{array}$ \\
\hline 19 & 1 & $1,3 \%$ \\
20 & 12 & $16 \%$ \\
21 & 50 & $66,7 \%$ \\
22 & 11 & $14,7 \%$ \\
23 & 1 & $1,3 \%$ \\
\hline Total & $\mathbf{7 5}$ & $\mathbf{1 0 0} \%$ \\
\hline
\end{tabular}

Tabel 2. Distribusi subjek penelitian menurut jenis kelamin

\begin{tabular}{ccc}
\hline $\begin{array}{c}\text { Jenis } \\
\text { kelamin }\end{array}$ & $\begin{array}{c}\text { Jumlah } \\
\text { subjek }\end{array}$ & $\begin{array}{c}\text { Persentasi } \\
\mathbf{( \% )}\end{array}$ \\
\hline Laki-laki & 39 & $52 \%$ \\
Perempuan & 36 & $48 \%$ \\
\hline Total & $\mathbf{7 5}$ & $\mathbf{1 0 0} \%$ \\
\hline
\end{tabular}

Distribusi tinggi badan sebelum tidur subjek penelitian laki-laki.

Pada tabel 3 dapat dilihat tinggi badan sebelum tidur subjek penelitian laki-laki dengan jumlah subjek 39 orang dengan rata-rata tinggi badan 166,8 $\mathrm{cm}$ dan standar deviasi 6,28. Dapat dilihat juga bahwa jumlah subjek laki-laki yang memiliki tinggi badan antara 165-169,9 cm adalah yang terbanyak yaitu sebanyak 13 orang ( $33,3 \%)$.

Tabel 3. Tinggi badan sebelum tidur subjek penelitian laki-laki

\begin{tabular}{cccc}
\hline $\begin{array}{c}\text { Tinggi Badan } \\
(\mathbf{c m})\end{array}$ & $\mathbf{N}$ & $\begin{array}{c}\text { Rata- } \\
\text { rata } \\
(\mathbf{c m})\end{array}$ & $\begin{array}{c}\text { Standar } \\
\text { deviasi } \\
(\mathbf{c m})\end{array}$ \\
\hline $150-154,9$ & 3 & 153,9 & 0,94 \\
$155-159,9$ & 1 & 158 & 0 \\
& & & \\
$160-164,5$ & 10 & 162,6 & 1,93 \\
$165-169,9$ & 13 & 167,3 & 1,20 \\
$\geq 170$ & 12 & 173,8 & 3,08 \\
\hline Total & $\mathbf{3 9}$ & $\mathbf{1 6 6 , 8}$ & $\mathbf{6 , 2 8}$ \\
\hline
\end{tabular}

Distribusi tinggi badan setelah bangun pagi subjek penelitian laki-laki

Pada tabel 4 dapat dilihat tinggi badan setelah bangun pagi subjek penelitian lakilaki dengan jumlah subjek 39 orang dengan rata-rata tinggi badan 167,8 cm dan standar deviasi 6,24. Dapat dilihat juga bahwa jumlah subjek laki-laki yang memiliki tinggi badan antara $>170 \mathrm{~cm}$ adalah yang terbanyak yaitu sebanyak 15 orang (38,5\%).

Tabel 4. Tinggi badan setelah bangun pagi subjek penelitian laki-laki

\begin{tabular}{cccc}
\hline $\begin{array}{c}\text { Tinggi Badan } \\
(\mathbf{c m})\end{array}$ & $\mathbf{N}$ & $\begin{array}{c}\text { Rata- } \\
\text { rata } \\
(\mathbf{c m})\end{array}$ & $\begin{array}{c}\text { Standar } \\
\text { deviasi } \\
(\mathbf{c m})\end{array}$ \\
\hline $150-154,9$ & 1 & 154,3 & 0 \\
$155-159,9$ & 2 & 155,9 & 0,07 \\
& & & \\
$160-164,5$ & 7 & 162,4 & 1,44 \\
$165-169,9$ & 14 & 167,8 & 1,33 \\
$\geq 170$ & 15 & 174,2 & 3,44 \\
\hline Total & $\mathbf{3 9}$ & $\mathbf{1 6 8 , 3}$ & $\mathbf{6 , 2 4}$ \\
\hline
\end{tabular}

Distribusi tinggi badan sebelum tidur subjek penelitian perempuan

Pada tabel di bawah ini dapat dilihat tinggi badan sebelum tidur subjek penelitian perempuan dengan jumlah subjek 36 orang dengan rata-rata tinggi badan 154,4 cm dan standar deviasi 5,44. Dapat dilihat juga bahwa jumlah subjek yang memiliki tinggi badan antara 155159,9 cm adalah yang terbanyak yaitu sebanyak 13 orang.

Tabel 5. Tinggi badan sebelum tidur subjek penelitian perempuan

\begin{tabular}{cccc}
\hline $\begin{array}{c}\text { Tinggi Badan } \\
(\mathbf{c m})\end{array}$ & $\mathbf{N}$ & $\begin{array}{c}\text { Rata- } \\
\text { rata } \\
(\mathbf{c m})\end{array}$ & $\begin{array}{c}\text { Standar } \\
\text { deviasi } \\
(\mathbf{c m})\end{array}$ \\
\hline $140-144,9$ & 1 & 140 & 0 \\
$145-149,9$ & 7 & 147,8 & 1,55 \\
& & & \\
$150-154,5$ & 9 & 152,5 & 1,65 \\
$155-159,9$ & 13 & 157,3 & 1,28 \\
$\geq 160$ & 6 & 161,2 & 1,76 \\
\hline Total & $\mathbf{3 6}$ & $\mathbf{1 5 4 , 4}$ & $\mathbf{5 , 4 4}$ \\
\hline
\end{tabular}


Distribusi tinggi badan setelah bangun pagi subjek penelitian perempuan

Pada tabel di bawah ini dapat dilihat tinggi badan setelah bangun pagi subjek penelitian perempuan dengan jumlah subjek 36 orang dengan rata-rata tinggi badan $156 \mathrm{~cm}$ dan standar deviasi 5,54. Dapat dilihat juga bahwa jumlah subjek yang memiliki tinggi badan antara 155$159,9 \mathrm{~cm}$ adalah yang terbanyak yaitu sebanyak 12 orang.

Tabel 6. Tinggi badan setelah bangun pagi subjek penelitian perempuan

\begin{tabular}{cccc}
\hline $\begin{array}{c}\text { Tinggi Badan } \\
(\mathbf{c m})\end{array}$ & $\mathbf{N}$ & $\begin{array}{c}\text { Rata- } \\
\text { rata } \\
(\mathbf{c m})\end{array}$ & $\begin{array}{c}\text { Standar } \\
\text { deviasi } \\
(\mathbf{c m})\end{array}$ \\
\hline $140-144,9$ & 1 & 141,9 & 0 \\
$145-149,9$ & 4 & 147,4 & 1,26 \\
& & & \\
$150-154,5$ & 9 & 152,5 & 1,29 \\
$155-159,9$ & 12 & 157,6 & 1,65 \\
$\geq 160$ & 10 & 162 & 1,83 \\
\hline Total & $\mathbf{3 6}$ & $\mathbf{1 5 6}$ & $\mathbf{5 , 5 4}$ \\
\hline
\end{tabular}

Uji perbedaan tinggi badan sebelum tidur dan setelah bangun pagi berdasarkan jenis kelamin.

Uji perbedaan menggunakan Paired Samples T-Test digunakan untuk menilai apakah perbedaan antara tinggi badan sebelum tidur dan setelah bangun pagi pada laki-laki dan perempuan bermakna secara statistik. Hasil menunjukkan perbedaan yang sangat bermakna antara tinggi badan sebelum tidur dan setelah bangun pagi pada laki-laki dan perempuan dengan nilai $\mathrm{p}$ $0,000(\mathrm{p}<0,01)$.

Tabel 7. Uji perbedaan tinggi badan sebelum tidur dan setelah bangun pagi berdasarkan jenis kelamin

\begin{tabular}{ccc}
\hline $\begin{array}{c}\text { Jenis } \\
\text { Kelamin }\end{array}$ & $\begin{array}{c}\text { Hasil Paired } \\
\text { Samples T-test }\end{array}$ & $\mathbf{p}$ \\
\hline Laki-Laki & 0,000 & $\mathrm{p}<0,01$ \\
Perempuan & 0,000 & $\mathrm{p}<0,01$ \\
\hline
\end{tabular}

Perbandingan peningkatan tinggi badan subjek penelitian laki-laki dan perempuan.

Pada tabel 8 dapat dilihat klasifikasi peningkatan tinggi badan, peningkatan terendah dan tertinggi serta rata-rata peningkatan pada keseluruhan subjek penelitian laki-laki dan perempuan yang berjumlah 75 orang. Didapatkan bahwa peningkatan tinggi badan terbanyak yaitu sebesar 1-2 cm dengan jumlah subjek 58 orang ( 77,33\% ), peningkatan $<1 \mathrm{~cm}$ sebanyak 6 orang ( $8 \%$ ), dan peningkatan $>2 \mathrm{~cm}$ sebanyak 11 orang ( $14,67 \%$ ) dengan rata-rata kenaikan sebesar 1,5 cm.

Tabel 8. Perbandingan peningkatan tinggi badan subjek penelitian laki-laki dan perempuan

\begin{tabular}{|c|c|c|c|c|}
\hline \multirow[t]{2}{*}{ Jenis Kelamin } & \multicolumn{3}{|c|}{ Peningkatan } & \multirow[t]{2}{*}{$\mathbf{n}$} \\
\hline & $<1$ & $1-2$ & $>2$ & \\
\hline Laki-Laki & 3 & 33 & 3 & 39 \\
\hline Perempuan & 3 & 25 & 8 & 36 \\
\hline Total & 6 & 58 & 11 & 75 \\
\hline
\end{tabular}

Pada tabel 9 dapat pula dilihat peningkatan terendah dan tertinggi berdasarkan jenis kelamin serta rata-rata peningkatan tinggi badan pada laki-laki dan perempuan. Rata-rata peningkatan tidak menunjukkan perbedaan hasil yang besar antara laki-laki dan perempuan.

Tabel 9. Peningkatan tertinggi dan terendah serta rata-rata peningkatan tinggi badan lakilaki dan perempuan

\begin{tabular}{cccc}
\hline \multirow{2}{\text{Jenis}}{} & \multicolumn{2}{c}{ Peningkatan } \\
Kelamin & $\begin{array}{c}\text { Terendah } \\
\mathbf{( c m )}\end{array}$ & $\begin{array}{c}\text { Tertinggi } \\
\mathbf{( c m )}\end{array}$ & $\begin{array}{c}\text { Rata- } \\
\text { Rata }\end{array}$ \\
Laki-Laki & 0,7 & 2,1 & 1,5 \\
Perempuan & 0,5 & 3,0 & 1,6 \\
\hline
\end{tabular}

\section{BAHASAN}

Keseluruhan subjek penelitian berusia 19-23 tahun. Pada umumnya proses pertumbuhan, khususnya tinggi badan pada seseorang telah berhenti pada usia di atas 18 tahun. ${ }^{4}$ Seluruh subjek penelitian telah melewati usia pertumbuhan, sehingga terjadinya pertambahan tinggi badan pada 
pengukuran pagi hari bukan disebabkan oleh proses pertumbuhan tinggi badan yang masih berlangsung.

Hasil pengukuran menunjukkan perbedaan postur tubuh antara laki-laki dan perempuan, dimana postur laki-laki lebih tinggi daripada perempuan. Perbedaan ini disebabkan oleh perbedaan growth spurt atau ledakan pertumbuhan antara laki-laki dan perempuan. Ledakan pertumbuhan adalah fase pertumbuhan dimana terjadi kenaikan pertumbuhan yang sangat cepat, dalam hal ini peningkatan tinggi badan pada usia remaja. Ledakan pertumbuhan pada perempuan sudah dimulai pada usia 10 tahun walaupun percepatan pertumbuhannya tidak terlalu besar, sedangkan pada laki-laki dimulai pada usia 12 tahun dengan percepatan pertumbuhan yang lebih besar dari perempuan sehingga mulai pada usia 13 tahun postur tubuh lakilaki lebih besar dari perempuan. ${ }^{5}$

Hasil pengukuran tinggi badan sebelum tidur dan setelah bangun pagi mengalami perbedaan, dimana tinggi badan subjek penelitian lebih tinggi jika diukur pada pagi hari dibandingkan pada malam hari. Perbadaan tinggi badan tersebut disebabkan oleh efek penipisan diskus intervertebralis yang berlangsung sepanjang hari yang disebabkan oleh beberapa faktor. Diskus intervertebralis adalah bagian yang terkena dampak dari kompresi yang terjadi pada tulang belakang akibat gravitasi, berat badan, maupun aktivitas manusia itu sendiri. Diskusintervertebralis menanggung 75\% dari total berat yang diterima tulang belakang. ${ }^{6}$ Kompresi yang terjadi disebut sebagai kompresi aksial, yaitu kompresi yang terjadi dari atas ke bawah. Kompresi aksial dengan tekanan paling kecil terjadi pada posisi berbaring daripada posisi berdiri. Kompresi yang terjadi akibat faktor-faktor di atas dapat menyebabkan tekanan yang terjadi dalam diskus meningkat dan terjadi kompensasi untuk menyeimbangkan tekanan di dalam diskus. Oleh karena itu, diskus mengalami pemipihan dan melebar serta nukleus pulposus menjadi datar. ${ }^{7}$
Faktor yang dapat menyebabkan terjadinya penipisan diskus intervertebralis yaitu posisi tubuh manusia. Posisi duduk dan berdiri memberikan tekanan yang tinggi pada tulang belakang. Posisi membungkuk, memutar, dan mengangkat beban akan meningkatkan tekanan lebih besar dari posisi berdiri dan duduk. Posisi berbaring merupakan posisi yang baik untuk mengurangi tekanan pada tulang belakang dan akan berdampak pada berkurangnya tekanan pada diskus intervertebralis. ${ }^{8}$ Tekanan yang berkurang akan memicu sifat elastisitas diskus sehingga diskus kembali ke ukuran semula.

Penelitian yang dilakukan oleh Wilke dkk (1999) menjelaskan besar tekanan yang bekerja pada diskus intervertebralis selama aktivitas tertentu. Dari penelitian tersebut, diketahui nilai tekanan yang bekerja pada diskus saat melakukan berbagai aktivitas. Contohnya, berbaring telungkup memberikan tekanan 0,1 $\mathrm{MPa}$, berbaring menyamping 0,12 MPa, berdiri tegak 0,5 $\mathrm{MPa}$, berdiri dengan posisi fleksi ke depan 1,1 MPa, dan mengangkat beban $20 \mathrm{~kg}$ 2,3 MPa. Dapat disimpulkan bahwa tidur merupakan posisi dengan tekanan intradiskus paling kecil, dan berdiri sambil mengangkat beban akan meningkatkan tekanan diskus sangat besar. ${ }^{9}$

Selain faktor posisi dan latihan selama aktivitas, faktor lain yang ikut berperan pada penelitian ini adalah beban yang bekerja pada tulang belakang. Beban yang bekerja dapat berupa berat badan, gravitasi, maupun beban tambahan yang bekerja seperti ketika membawa tas punggung. Teori sebelumnya yang dikemukakan oleh Kapandji (1974) mengatakan bahwa terdapat perbedaan ketebalan diskus pada sebelum penambahan beban dan saat penambahan beban. Pada orang normal tanpa gangguan pada diskus intervertebralis, diskus intervertebralis akan mengalami pemipihan $1.4 \mathrm{~mm}$ dan pelebaran pada pembebanan sebesar $100 \mathrm{~kg}$ dan menjadi lebar. Hal yang berbeda akan terjadi pada orang dengan gangguan diskus intervertebtralis, dimana diskus akan mengalami pemipihan $2 \mathrm{~mm}$ dan pelebaran 
Pattudju, Tanudjaja, Kaseke: Gambaran tinggi badan sebelum tidur ...

dengan pembebanan yang sama. ${ }^{6}$

Penelitian yang dilakukan oleh Kimura dkk (2001) sesuai dengan teori sebelumnya, dimana pembebanan dapat mempengaruhi ketebalan diskus intervertebralis. Selama pembebanan, tinggi diskus dapat berkurang sehingga mempengaruhi tinggi kolumna vertebralis selama kompresi. Pengurangan signifikan hanya terjadi pada L4-L5 selama kompresi. ${ }^{10}$ Hal tersebut juga sesuai dengan penelitian O'Connell dkk (2007) ${ }^{3}$. Percobaan yang dilakukan Iatridis dkk (1999) pada tikus juga didapatkan perubahan kolumna vertebra tikus selama pemberian beban pada ekor tikus. ${ }^{11}$

Sifat elastisitas diskus intervertebralis berguna untuk mengembalikan tinggi dan volume diskus yang berkurang ketika terjadi kompresi pada kolumna vertebralis. Waktu pemulihan setelah pemberian tekanan sangat mempengaruhi kemampuan elastisitas diskus. Diskus harus diberi waktu pemulihan yang cukup untuk dapat mengembalikan ukuran diskus seperti semula sebelum diberikan tekanan yang baru.

Penelitian O’Connell (2010) menunjukkan bahwa diskus intervertebralis dapat mengalami pemulihan sebesar $70 \%$ setelah tekanan yang bekerja dihilangkan dan mencapai pemulihan sempurna dalam waktu 8 jam. $^{12}$ Hasil penelitian dapat diterapkan bagi upaya kesehatan kerja, khususnya bagi para pekerja-pekerja yang berhubungan dengan beban, seperti kuli angkut pelabuhan, pekerja bangunan, dan tukang jamu gendong. Setelah beraktivitas, terutama aktivitas yang berhubungan dengan beban dianjurkan untuk tidur \pm 8 jam pada malam hari untuk mengembalikan ukuran diskus seperti semula.

\section{SIMPULAN}

Berdasarkan penelitian mengenai gambaran tinggi badan sebelum tidur dan setelah bangun pagi pada mahasiswa semester VII Fakultas Kedokteran Unsrat, disimpulkan bahwa:

1. Terdapat perbedaan tinggi badan antara laki-laki dan perempuan, dimana laki-laki memiliki postur tubuh lebih tinggi daripada perempuan.

2. Terdapat perbedaan tinggi badan yang bermakna pada waktu pengukuran sebelum tidur dan setelah bangun pagi, dimana terjadi peningkatan tinggi badan jika diukur pada pagi hari dibandingkan pada malam hari.

3. Rata-rata peningkatan tinggi badan yang terjadi pada laki-laki yaitu sebesar $1,5 \mathrm{~cm}$ sedangkan pada perempuan $1,6 \mathrm{~cm}$.

\section{SARAN}

Perlu dilakukan penelitian mengenai pengukuran tinggi badan pagi dan malam hari pada subjek dengan banyak aktivitas dan tingkat paparan beban yang besar, seperti tukang angkut barang dan tukang jamu gendong.

\section{UCAPAN TERIMA KASIH}

Ucapan terima kasih disampaikan kepada Dr. dr. S. Tjandra Wangko, MSi, PA(K) dan dr. Djon Wongkar, MKes, AIFO selaku penguji skripsi yang telah memberikan kritikan dan saran, serta semua pihak, baik secara langsung maupun tidak langsung, yang telah memberikan ide dan gagasan kepada penulis.

\section{DAFTAR PUSTAKA}

1. National Health and Nutrition Examination Survey. Anthropometry Procedures Manual.2004:1.

2. Roush JR, Kee M, Toeppe J. Change in Vertebral Colum Height (VCH) at Different Distance Intervals during a 3mile walk. North America Journal Of Sport Physical Therapy [serial on the internet]. 2008 [cited 2015 Jan 3]; 3(3):145-150

availablefrom:http://www.ncbi.nlm.nih.g ov/pmc/articles/PMC2953332/.

3. O'Connell GD, Johannessen W, Vresilovic EJ, Elliot DM. Human Internal Disc Strains in Axial Compression Measured Noninvasively Using Magnetic Resonance Imaging. SPINE. Lippincott William \& Wilkins 
INC.2007;33(25):2860-8.

4. Batubara JRL. Adolescent Development. Sari Pediatri. 2010;12(1):21-9.

5. Artaria MD. Perbedaan antara laki-laki dan perempuan: Penelitian antropometri pada anak-anak umur 6-19 tahun. Jurnal Kebudayaan Masyarakat dan Politik. 2010;22(4):343-9

6. Kapandji IA. The Physiology of the Joints Vol.3: The Trunk and the VertebralColumn.New York:Churchill Livingstone; 1974.

7. Tanudjaja GN. Hubungan antara Proporsi Panjang Segmen dan Indeks Curvatura Thoracolumbalis dengan Mobilitas Truncus pada pesenam dan bukanpesenam.[Thesis].[Yogyakarta]:Un iversitas Gadjah Mada;1992.

8. Kurnik JD. Exercises for Back Pain: LowCompression Training Program. [serial on the internet]. 2012 [cited 2015 Jan 9]; 33(1) Available from :http://www.dynamicchiropractic.com/m pacms/dc/article.php?id=56526

9. Wilke HJ, Peter N, Caimi M, Hoogland
T, Claes LE. New In Vivo Measurements of Pressure in the Intervertebral Disc in Daily Life. SPINE. Lippincott William and Wilkins Inc. 1999;24(8):755-62.

10. Kimura S, Steinbach G, Adusumalli M, Abitbol J, Watenpaugh D, Hargens A. Lumbar Spine Length and Curvature Responses to an Axial Load Using an MRI -compatible Compression Harness. World Spine 1 Berlin; 2000 Aug 27:1-4

11. Iatridis JC, Mente PL, Stokes IAF, Aronsson DD, Alini M. CompressionInduced Changes in Intervertebral Disc Properties in a Rat Tail Model. SPINE. Lippincott William \& Wilkins. 1999;24(10):996-1002

12. O'Connell GD, Jacobs NT, Sen S, Vresilovic EJ, Elliot DM. Axial Creep loading and unloaded recovery of the human intervertebral disc and the effect of degeneration. Journal of The Mechanical Behavior of Biomedecal Materials. 2011;4:933-942. 